\title{
Analisis Posisi Bersaing dan Strategi Bauran Pemasaran untuk Meningkatkan Jumlah Kunjungan Pada Handara Golf and Resort di Bedugul Bali
}

\author{
Rosalia Nita Aryani, Ni Made Rustini dan Ni Made Taman Sari \\ Fakultas Ekonomi, Universitas Warmadewa Denpasar \\ *nita.aryani@gmail.com
}

How to cite (in APA style):

Aryani, R, N., Rustini, N, M., Sari N, M, T. (2020). Analisis Posisi Bersaing dan Strategi Bauran Pemasaran untuk Meningkatkan Jumlah Kunjungan Pada Handara Golf and Resort di Bedugul Bali. 19(2), pp.91-97. https:// doi.org/10.22225/we.19.2.2318.91-97

\begin{abstract}
This research to determine the competitive position based on the Boston Consulting Group matrix, to find out internal variables including strengths and weaknesses as well as external variables including opportunities and threats and to find out relevant marketing mix strategies to increase the number of visits. The study was conducted at Handara Golf and Resort in Bedugul Bali. Data analysis techniques used are the Boston Consulting Group matrix analysis and SWOT analysis. The analysis shows that using BCG matrix analysis, the company is in the position of dogs with a growth rate of $7.09 \%$ and an analysis of market share of 0.17 . Using a SWOT analysis shows that the most dominant external opportunity variable with the acquisition of 3.80 results. Where the opportunity indicator is an increase in the number of tourists, growth in online sales, buyers want more images in electronic commerce or e-commerce when buying a product, most of the time on mobile devices is used, social media plays a major role in the distribution of most of the time used on mobile devices, technological advances over the use of social media, per capita income growing in Indonesia, located in the Pacific Ring of Fire, new regulations from Bank Indonesia. While the threat indicator is providing alternative tourist attractions throughout Indonesia to tourists other than in Bali and losing followers in the social media, it can be concluded that companies need to implement a turn-around strategy because external opportunities are more oriented to supporting the company's Handara Golf and Resort Bali.
\end{abstract}

Keywords: Competitive position; marketing mix; number of visits

\begin{abstract}
Abstrak
Penelitian ini bertujuan untuk mengetahui posisi bersaing berdasarkan matrik Boston Consulting Group, untuk mengetahui variabel internal yang termasuk kekuatan dan kelemahan serta variabel eksternal yang termasuk peluang dan ancaman dan untuk mengetahui strategi bauran pemasaran yang relevan untuk meningkatkan jumlah kunjungan. Penelitian dilakukan pada Handara Golf and Resort di Bedugul Bali. Teknik analisis data yang digunakan adalah analisis matrik Boston Consulting Group dan analisis SWOT. Hasil analisis menunjukkan bahwa menggunakan analisis matrik BCG, perusahaan berada pada posisi anjing (dogs) dengan tingkat pertumbuhan sebesar 7,09\% dan analisis pangsa pasar sebesar 0,17 . Dengan menggunakan analisis SWOT menunjukkan bahwa variabel peluang eksternal yang paling mendominasi dengan perolehan hasil 3,80. Dimana indikator peluangnya adalah peningkatan jumlah wisatawan, pertumbuhan jumlah penjualan secara online, pembeli menginginkan lebih banyak gambar pada perdagangan elektronik atau e-commerce pada saat membeli suatu produk, sebagian besar waktu di perangkat seluler digunakan diaplikasi, sosial media berperan besar pada pendistribusian sebagian besar waktu yang digunakan di perangkat seluler, kemajuan teknologi atas penggunaan sosial media, pendapatan perkapita bertumbuh di Indonesia, berlokasi di cincin api pasifik, peraturan baru dari Bank Indonesia. Sedangkan yang menjadi indikator ancaman adalah menyediakan alternatif tempat wisata lainnya diseluruh Indonesia kepada wisatawan selain di Bali dan kehilangan pengikut disosial media, maka dapat disimpulkan bahwa perusahaan perlu menerapkan strategi turn-around karena peluang eksternal lebih berorientasi untuk mendukung perusahaan Handara Golf and Resort Bali.
\end{abstract}

Kata Kunci: Posisi Bersaing; Bauran Pemasaran; Jumlah Kunjungan 


\section{PENDAHULUAN}

Di dalam beberapa tahun terakhir pariwisata telah tumbuh berkembang di Indonesia, jumlah wisatawan juga terus mengalami peningkatan dari tahun ke tahun. Hal - hal yang menarik perhatian para wisatawan selain menikmati keindahan alam dan mengenal ragam budaya, juga ditawarkan berbagai macam aktivitas dan hiburan selama wisatawan mengunjungi Indonesia khususnya Bali. Dari sekian banyak aktivitas yang ditawarkan ada salah satu aktivitas yang tidak kalah menarik yaitu olahraga golf. Walaupun olahraga golf hanya cukup populer untuk kalangan kelas menengah ke atas.

Persaingan antar perusahaan golf yang ada di Bali juga terjadi. Di Bali sendiri ada lima lapangan golf yang memberikan sensasi tersendiri bagi para pecinta olahraga golf, seperti situasi lapangan, jenis rumput, kesulitan atau tantangan yang didapat pada saat bermain golf dan kondisi geografis dari masing - masing lapangan. Walaupun jumlah perusahaan pesaing dari bisnis golf ada sedikit di Bali akan tetapi cara pengelolaan lapangan yang baik serta kondisi alam yang berbeda memberikan tantangan tersendiri yang menjadi daya tarik bagi para pegolfer.

Strategi pemasaran yang baik akan mampu membawa perusahaan lebih unggul daripada perusahaan pesaingnya maka dapat diterapkan strategi bauran pemasaran yang sering disingkat dengan 7P yang terdiri dari product, price, place, promotion, process, people dan physical evidence, sekarang dalam era pemasaran digital telah berkembang sehingga didefinisikan ulang menjadi 4C yaitu menciptakan bersama (co-creation), mata uang (currency), aktivasi komunal (communal activation), dan percakapan (conversation). Strategi pemasaran adalah serangkaian tujuan dan sasaran, kebijakan, dan aturan yang memberi arah kepada usaha - usaha pemasaran perusahaan dari waktu ke waktu, pada masing - masing tingkatan dan acuan serta lokasinya, terutama sebagai tanggapan perusahaan dalam menghadapi lingkungan dan keadaan persaingan yang selalu berubah.

Handara Golf and Resort di Bedugul Bali beralamat di Desa Singaraja - Denpasar, Pancasari, Sukasada, Pancasari, Bedugul, Kabupaten Buleleng. Produk yang ditawarkan adalah permainan golf 18 holes, permainan golf 9 holes, tambahan putaran 18 holes, tambahan putaran 9 holes, permainan golf untuk junior 18 holes, latihan di driving range, latihan di lapangan, penyewaan premium golf bag, penyewaan reguler golf bag, penyewaan sepatu golf, bola untuk latihan per 50 bola. Karena yang ditawarkan adalah berupa jasa maka lokasi fisik tempat terjadinya pelayanan antara pengunjung dan perusahaan adalah di Handara Golf and Resort di Bedugul Bali.

Perusahaan pesaingnya adalah New Kuta Golf and Ocean View, Bali National Golf Club, Bali Beach Golf Course and Sector Bar, Bukit Pandawa Golf and Country Club. Dari ke-empat pesaing ada satu pesaing terkuat yaitu New Kuta Golf and Ocean View. New Kuta Golf and Ocean View beralamat di Kawasan Pecatu Indah Resort Jalan Raya Uluwatu, Pecatu, Kuta Selatan, Badung. Produk yang ditawarkan juga sama dengan produk yang ditawarkan di Handara Golf and Resort di Bedugul Bali.

Dilihat dari harga diketahui bahwa New Kuta Golf and Ocean View menawarkan harga yang sedikit lebih mahal dibandingkan dengan Handara Golf and Resort di Bedugul Bali akan tetapi total jumlah kunjungan di New Kuta Golf and Ocean View masih 4 kali lipat lebih banyak dibandingkan dengan jumlah kunjungan di Handara Golf and Resort di Bedugul Bali.

Strategi pemasaran yang dilakukan oleh Handara Golf and Resort Bali dalam upaya meningkatkan jumlah kunjungan selain beriorientasi pada produk, harga, promosi, tempat, orang orang yang terlibat dalam sistem pendistribusian, bukti fisik suatu pelayanan dan kondisi fisik pelayanan. Perusahaan seharusnya melakukan pengembangan produk baru yang melibatkan pelanggan untuk menciptakan suatu produk unggulan, menggunakan alat pembayaran mata uang rupiah yang sudah disahkan oleh Bank Indonesia, menyediakan layanan yang bisa diakses dengan mudah ke produk dan layanan yang bukan milik perusahaan sendiri melainkan milik pelanggan lain dan melakukan respon terhadap pesan - pesan kepada pelanggan melalui media sosial yang semakin marak di era digital.

Unsur - unsur yang dimiliki perusahaan adalah faktor eksternal peluang yang dibangun pada saat membangun bisnis untuk menghasilkan keuntungan termasuk daftar apa saja yang memungkinkan bisnis mampu bertahan dan diterima masyarakat jangka pendek dan jangka panjang, faktor eksternal ancaman untuk mengetahui apakah perusahaan bisa bertahan dimasa depan atau tidak, kemudian ada faktor internal kekuatan yang dimiliki perusahaan dalam menganalisis kelebihan 
yang dimiliki perusahaan, dan faktor internal kelemahan yang menjadi batasan bagi perusahaan.

Beberapa penelitian terkait dengan posisi bersaing dan strategi bauran pemasaran telah dikaji sebelumnya oleh beberapa peneliti seperti; Rustini (2015) dalam hasil penelitiannya bahwa hasil analisis SWOT dilihat dari variabel internal yang menunjukkan kekuatan perusahaan, dengan nilai bobot masing-masing indikator yang diperoleh adalah sebesar 3,09. Adapun kekuatan Pia Sinardi Baturiti Company terletak pada indikator merek, kualitas, rasa dan kelemahan pada indikator saluran distribusi, promosi dan pengemasan. Strategi yang harus diterapkan Perusahaan Pia Sinardi Baturiti adalah strategi agresif/SO yang berorientasi pada kekuatan Perusahaan Pia Sinardi Baturiti. Selanjutnya, dalam hasil penelitian dari Sumartini \& Ariwiguna (2019) menunjukkn bahwa dilihat dari variabel ekternalnya dengan nilai tertimbang 2,43 indikator yang menjadi peluang terletak pada indikator perkembangan kunjungan wisatawan, kebudayaan Bali, perkembangan teknologi serta keamanan Bali sedangkan ancaman yang dimiliki Budhi Ayu Silver meliputi indikator kondisi perekonomian, perusahaan pesaing dan stabilitas politik.

Berdasarkan uraian latar belakang masalah, maka dapat dirumuskan suatu pokok permasalahan sebagai berikut :

Bagaimanakah posisi bersaing berdasarkan matrik Boston Consulting Group pada Handara Golf and Resort Bali?

Apakah yang menjadi kekuatan, kelemahan, peluang dan ancaman dari Handara Golf and Resort Bali?

Bagaimanakah strategi bauran pemasaran yang relevan untuk meningkatkan jumlah kunjungan pada Handara Golf and Resort Bali?

Adapun tujuan dalam pelaksanaan penelitian adalah sebagai berikut :

Untuk mengetahui bagaimanakah posisi bersaing berdasarkan matrik Boston Consulting Group pada Handara Golf and Resort Bali.

Untuk mengetahui kekuatan, kelemahan, peluang dan ancaman dari Handara Golf and Resort Bali.

Untuk menentukan strategi bauran pemasaran yang relevan untuk meningkatkan jumlah kunjungan pada Handara Golf and Resort Bali.

\section{TINJAUAN PUSTAKA}

\section{Strategi Bersaing}

Strategi bersaing dapat diartikan sebagai cara untuk menarik perhatian konsumen dan dalam pelaksanaannya perusahaan dihadapkan pada situasi dan lingkungan pasar yang spesifik, yang memerlukan berbagai variasi (Limakrisna \& Purba, 2017:59).

Unsur strategi persaingan dapat dikelompokkan menjadi tiga, yaitu: (Rangkuti, 2017:102).

Segmentasi pasar terpisah.

Tindakan mengidentifikasikan dan membentuk kelompok pembeli atau konsumen secara

Targetting

Tindakan memilih satu atau lebih segmen pasar yang akan dimasuki.

Positioning

Penetapan posisi pasar yang bertujuan untuk membangun dan mengkomunikasikan keunggulan bersaing produk yang ada di pasar ke dalam benak konsumen.

\section{Strategi Pemasaran}

Strategi pemasaran adalah serangkaian tujuan dan sasaran, kebijakan dan aturan yang memberi arah kepada usaha - usaha pemasaran perusahaan dari waktu ke waktu, pada masing - masing tingkatan dan acuan serta lokasinya, terutama sebagai tanggapan perusahaan dalam menghadapi lingkungan dan keadaan persaingan yang selalu berubah (Assauri, 2014:168).

Faktor - faktor yang mempengaruhi rencana strategis pemasaran adalah: (Assauri, 2014:185).

Strategi penetrasi pasar 
Strategi yang bertujuan untuk meningkatkan posisi perusahaan yang dihubungkan dengan produk dan pasar yang sedang dilayani perusahaan sekarang ini.

Strategi pengembangan produk

Strategi ini menekankan pada peningkatan mutu dari produk yang dipasarkan perusahaan saat ini dengan sasaran pasar yang dituju sama.

Strategi integrasi vertikal

Strategi ini bertujuan meningkatkan rentabilitas (profability), efisiensi, dan pengendalian melalui penggabungan atau integrasi dengan perusahaan yang ada hubungannya dengan proses produksi yang dijalankan selama ini.

Strategi synergitistic diversification

Strategi yang memasuki pasar baru tanpa mengetahui berhasil atau tidaknya produk baru yang dikeluarkan ke pasar.

Strategi conglomerate diversification

Strategi ini bertujuan untuk menarik kelompok konsumen baru melalui diversifikasi pada produk yang tidak memiliki hubungan teknologi, produk dan pasar yang dilayani perusahaan saat ini.

\section{Bauran Pemasaran}

Marketing mix merupakan kombinasi variabel atau kegiatan yang merupakan inti dari sistem pemasaran, variabel yang dapat dikendalikan oleh perusahaan untuk mempengaruhi reaksi para pembeli atau konsumen (Assauri, 2014:198). Bauran pemasaran terdiri dari 7P yaitu produk, harga, promosi, tempat, orang, bukti fisik, dan proses. Yang mana ketujuh variabel ini saling berkaitan dalam penentuan keberhasilan strategi pemasaran.

Di dalam era ekonomi digital bauran pemasaran telah berkembang mengakomodasi lebih banyak partisipan pelanggan sehingga didefinisikan ulang menjadi 4C, yaitu: (Kotler, Kartajaya, \& Setiawan, 2019:47).

Menciptakan bersama (co-creation)

Strategi pengembangan produk baru dan pelibatan pelanggan dalam tahap awal terbentuknya gagasan, dapat meningkatkan laju kesuksesan dari pengembangan produk baru dan kemampuan mempersonalisasikan produk dan jasa sehingga menciptakan proposisi nilai unggulan.

Mata uang (currency)

Di dalam ekonomi digital, harga mirip dengan mata uang yang berfluktuasi sesuai permintaan pasar. Mengoptimalkan profitabilitas dengan mengenakan biaya berbeda pada setiap pelanggan.

Aktivasi komunal (communal activation)

Konsep saluran pendistribusian yang berubah yaitu distribusi rekan ke rekan yang menyediakan akses mudah ke produk dan layanan yang bukan milik dari perusahaan sendiri, melainkan milik pelanggan lain.

Percakapan (conversation)

Di era digital konsep promosi yang awal mulanya komunikasi satu sisi, sekarang maraknya media sosial memungkinkan pelanggan melakukan respon terhadap pesan - pesan itu dan memungkinkan pelanggan berbicara tentang pesan - pesan itu dengan pelanggan lain.

\section{Matrik BCG}

Analisis matrik BCG adalah sebuah matriks yang memungkinkan bagi manajer untuk mengelola portfolio atau kumpulan bisnis korporasi secara efisien dan efektif. Matriks ini pertama kali dikembangkan oleh Boston Consulting Group, yang memperkenalkan ide bahwa setiap bisnis korporasi dapat dievaluasi dan diplot ke dalam sebuah matriks berukuran 2 x 2 untuk mengidentifikasi bisnis mana saja yang memiliki potensi pertumbuhan dan pangsa pasar yang tinggi. Sumbu horisontal menggambarkan pangsa pasar, yang dievaluasi sebagai rendah atau tinggi, sedangkan sumbu vertikal menggambarkan prediksi tingkat pertumbuhan pasar, yang juga dievaluasi sebagai rendah atau tinggi (Hery, 2017:104). 


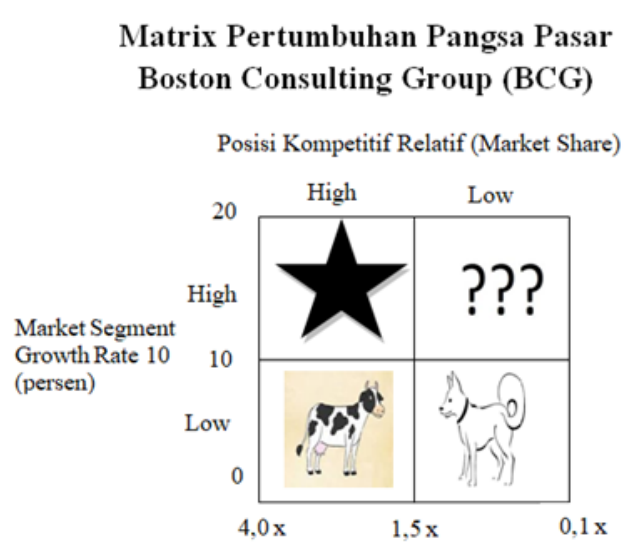

Sumber : Freddy Rangkuti (2017:89)

Pertumbuhan tinggi/Posisi persaingan tinggi (The Stars)

Bisnis pada posisi ini menghadapi pasar yang sangat cepat dengan pangsa pasar yang rendah. Stars merupakan kemungkinan jangka panjang terbaik. Bisnis ini memerlukan investasi untuk memperkuat posisi dominannya di dalam pasar yang sedang tumbuh. Tetapi perusahaan perlu berhati - hati walaupun posisi sedang kuat, bisa saja tidak cukup untuk membiayai pertumbuhan yang cepat.

Pertumbuhan rendah/Posisi persaingan tinggi (Cash Cows)

Pasar dalam kondisi telah dewasa, tingkat pertumbuhan relatif rendah. Karena disebabkan posisinya yang relatif kuat, perusahaan disarankan untuk mengadakan investasi pada Stars/Question Mark.

Pertumbuhan rendah/Posisi persaingan rendah (The Dogs)

Perusahaan menghadapi pangsa pasar yang rendah sekaligus pertumbuhan yang lamban. Cash flow yang rendah dan negatif disebabkan oleh kompetisi yang lemah. Apabila diperlukan investasi untuk mempertahankan pangsa pasar, akan lebih baik melaksanakan divest dan investasi yang direlokasikan untuk membiayai Stars/Question Mark.

Pertumbuhan tinggi/Posisi persaingan rendah (Question Mark)

Perusahaan menghadapi pangsa pasar yang rendah akan tetapi pertumbuhan yang tinggi yang memberikan kesan seolah - olah perputaran uang lemah. Investasi diperlukan untuk menciptakan perusahaan ke arah pasar Stars, akan tetapi hal ini bisa sangat berbahaya bagi perusahaan.

\section{Analisis SWOT}

Salah satu alat yang dipakai adalah analisis SWOT untuk menggambarkan bagaimana peluang dan ancaman yang dihadapi perusahaan dapat disesuaikan dengan kekuatan dan kelemahan yang dimiliki perusahaan. Menurut Rangkuti (2017:83) matriks SWOT dapat menghasilkan empat set kemungkinan alternatif strategis yang dapat digambarkan sebagai berikut:

Tabel 1

Diagram Matrik SWOT

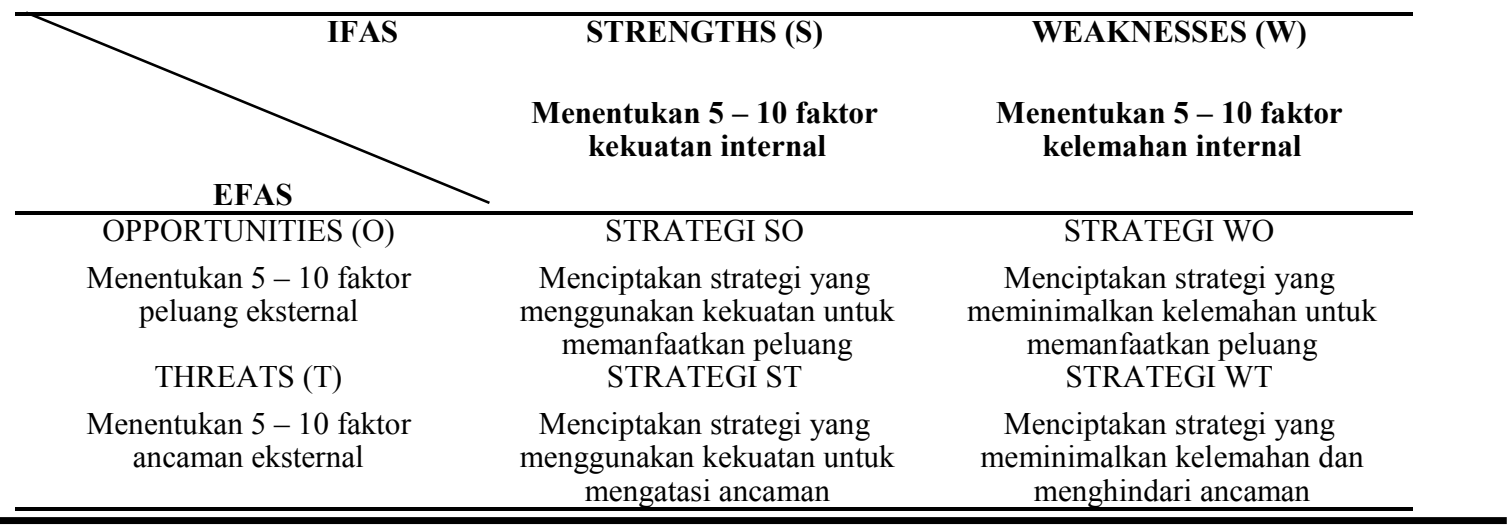




\section{METODE}

Penelitian ini dilakukan pada Handara Golf and Resort Bali yang berlokasi di Desa Singaraja, Kabupaten Buleleng. Data yang dikumpulkan adalah data primer, data sekunder, data kuantitatif dan data kualitatif. Metode pengumpulan data melalui observasi, kuesioner, wawancara dan studi dokumentasi selanjutnya data yang telah terkumpul dianalisis menggunakan analisis Matrix Boston Consulting Group untuk mengetahui tingkat pertumbuhan pasar dan pangsa pasar relatif serta dilakukan analisis SWOT.

\section{PEMBAHASAN}

Berdasarkan hasil analisis pertumbuhan pada Handara Golf and Resort Bali adalah sebesar $7,09 \%$ dan angka tersebut dibawah $10 \%$ yang berarti peluang bisnis yang ada di pasar dimana perusahaan melayani pengunjung adalah rendah. Dari analisis pangsa pasar relatif diketahui sebesar 0,17 , dimana angka tersebut dibawah 1 . Ini berarti perusahaan memiliki pangsa pasar yang lebih rendah dibandingkan perusahaan pesaing.

Maka dapat ditarik kesimpulan bahwa posisi bersaing Handara Golf and Resort Bali berada pada posisi anjing (dogs), artinya indikator bagi keadaan Strategic Unit Business dimana pangsa pasar rendah dan tingkat pertumbuhan juga lamban. Strategi yang diterapkan adalah meningkatkan penjualan melalui online telemarketing, meningkatkan kualitas produk, meninjau kembali harga, menjaga hubungan baik dengan pengunjung, memberikan penawaran spesial kepada pada anggota dan pengunjung lain, mempromosikan produk menggunakan marketing online, dan mempromosikan keadaan lingkungan yang bisa menjadi daya tarik bagi pengunjung.

Berdasarkan penilaian faktor variabel internal sebesar 2,98, yang menunjukkan kategori cukup puas. Ini berarti faktor kekuatan internal masih mendominasi dibandingkan faktor kelemahan internal, diketahui indikator kekuatan Handara Golf and Resort Bali adalah suhu udara dipegunungan, tidak berada di zona keramaian, lapangan golf sekaligus resort, harga bermain 18 holes lebih murah daripada dengan harga pesaingnya, pengunjung menyukai lokasi dan kualitas lapangan golf, sejarah lapangan. Sedangkan indikator kelemahannya adalah jumlah pengikut di akun facebook tidak terlalu banyak, internet lambat, lokasi jauh dari tempat - tempat pariwisata di Bali, fasilitas yang ditawarkan tidak sesuai harapan pengunjung, staff tidak bisa berbahasa Inggris dengan lancar.

Sedangkan hasil penelitian terhadap variabel eksternal pada Handara Golf and Resort Bali adalah 3,8 yang menunjukkan kategori puas. Dimana faktor peluang eksternal lebih mendominasi daripada faktor ancaman eksternal. Diketahui faktor peluang eksternal Handara Golf and Resort Bali adalah peningkatan jumlah wisatawan, pertumbuhan jumlah penjualan secara online, pembeli menginginkan lebih banyak gambar pada perdagangan elektronik atau e-commerce pada saat membeli suatu produk, sebagian besar waktu di perangkat seluler digunakan diaplikasi, sosial media berperan besar pada pendistribusian sebagian besar waktu yang digunakan di perangkat seluler, kemajuan teknologi atas penggunaan sosial media, pendapatan perkapita bertumbuh di Indonesia, berlokasi di cincin api pasifik, peraturan baru dari Bank Indonesia. Sedangkan yang menjadi indikator ancaman adalah menyediakan alternative tempat wisata lainnya diseluruh Indonesia kepada wisatawan selain di Bali dan kehilangan pengikut disosial media.

Berdasarkan diagram SWOT, Strategi bauran pemasaran yang strategi turn-around dimana situasi perusahaan pada posisi ini adalah perusahaan menghadapi peluang pasar yang sangat besar akan tetapi menghadapi beberapa kendala kelemahan internal perusahaan. Fokus strategi perusahaan adalah meminimalkan masalah - masalah internal perusahaan sehingga dapat merebut pasar persaingan dengan lebih baik.

\section{SIMPULAN}

Analisis tingkat pertumbuhan pasar pada Matrik Boston Consulting Group adalah sebesar $7,09 \%$ dimana hasil ini dibawah $10 \%$ dan hasil analisis pangsa pasar relatif adalah sebesar 0,17 dimana hasilnya dibawah 1 . Maka terlihat posisi perusahaan berada pada posisi anjing (dogs) dimana pangsa pasar rendah dan tingkat pertumbuhan pasar juga rendah. 
Dari analisis SWOT diketahui kekuatan, kelemahan, peluang dan ancaman dari Handara Golf and Resort Bali dalam meningkatkan jumlah kunjungan. Dari variabel internal diperoleh hasil sebesar 2,98 sehingga yang menjadi kekuatan antara lain suhu udara di pegunungan, tidak berada di zona keramaian, lapangan golf sekaligus resort, harga bermain 18 holes lebih murah daripada harga pesaingnya, pengunjung menyukai lokasi dan kualitas lapangan, dan sejarah lapangan.

Dilihat dari variabel eksternal diperoleh hasil sebesar 3,8 dengan indikator peluangnya antara lain peningkatan jumlah wisatawan, pertumbuhan jumlah penjualan secara online, pembeli menginginkan lebih banyak gambar pada perdagangan elektronik atau e-commerce pada saat membeli suatu produk, sebagian besar waktu di perangkat seluler digunakan di aplikasi, sosial media berperan besar pada pendistribusian sebagian besar waktu yang digunakan di perangkat seluler, pendapatan perkapita bertumbuh di Indonesia, lokasi di "Cincin Api Pasifik", dan peraturan baru dari Bank Indonesia.

Strategi bauran pemasaran yang sebaiknya diterapkan adalah strategi turn-around maupun strategi SO yang berorientasi pada pertumbuhan dan pertahanan. Strategi yang dirancang untuk menggunakan kekuatan perusahaan dengan memanfaatkan peluang - peluang guna meningkatkan jumlah kunjungan sekaligus meningkatkan laba perusahaan.

\section{DAFTAR PUSTAKA}

Assauri, S. (2014). Manajemen Pemasaran: Dasar, Konsep dan Strategi (Kesatu). Jakarta.

Hery. (2017). Cara Cepat dan Mudah Memahami Pengantar Manajemen (Kedua). Yogyakarta: Gava Medika.

Kotler, P., Kartajaya, H., \& Setiawan, I. (2019). Marketing 4.0 Bergerak Dari Tradisional Ke Digital. Jakarta: PT Gramedia Pustaka Utama.

Limakrisna, N., \& Purba, T. P. (2017). Manajemen Pemasaran: Teori dan Aplikasi dalam Bisnis. Jakarta: Mitra Wacana Media.

Rangkuti, F. (2017). Analisis SWOT: Teknik Membedah Kasus Bisnis Cara Perhitungan Bobot, Rating, dan OCAI. Jakarta: PT Gramedia Pustaka Utama.

Rustini, N. M. (2015). Analisis Posisi Bersaing dan Penentuan Strategi Bauran Pemasaran untuk Meningkatkan Nilai Penjualan pada Perusahaan Kue Pia Sinardi Baturiti. Jurnal Ilmu Manajemen (JUIMA), 5(1). Retrieved from http://jurnal.unmas.ac.id/index.php/JUIMA/article/view/126

Sumartini, A. R., \& Ariwiguna, I. G. P. (2019). Analisis Posisi Bersaing dan Penentuan Strategi Bauran Pemasaran untuk Meningkatkan Nilai Penjualan pada Budhi Ayu Silver di Celuk Sukawati Gianyar. Warmadewa Management and Business Journal (WMBJ), 1(1), 9-18. doi:https://doi.org/10.22225/ wmbj.1.1.1009.9-18 